\title{
Thermodynamic Characterisation of Steel Corrosion for the Corrosion Inhibition of Steel in Sulphuric Acid Solutions by Artemisia
}

\author{
M. Bouklah, B. Hammouti * \\ Laboratoire de Chimie des Eaux et Corrosion, Faculté des Sciences, B.P. 717, Oujda, Morocco
}

Received 1 December 2005; accepted in revised form 8 November 2006

\begin{abstract}
The effect of natural occurring extract of artemisia on the corrosion of steel in $0.5 \mathrm{M}$ $\mathrm{H}_{2} \mathrm{SO}_{4}$ in the temperature range $298-353 \mathrm{~K}$ is studied by weight loss method, electrochemical polarisation and linear polarisation $R_{p}$ measurements. Results obtained reveal that extract reduces the corrosion rate. The inhibition efficiency increases with the increase of artemisia content at $10 \mathrm{~g} / \mathrm{L}$ to reach $95 \%$ and $99 \%$ at 298 and $353 \mathrm{~K}$, respectively. Results obtained by gravimetric and electrochemical polarisation are in good agreement. Polarisation studies clearly reveal that the presence of the natural artemisia does not change the mechanism of the hydrogen evolution reaction and acts as a mixed type inhibitor. The inhibition efficiency increases with temperature. The adsorption of artemisia on the steel follows Langmuir adsorption isotherm.
\end{abstract}

Keywords: steel, artemisia, inhibition, corrosion, acid, natural substance.

\section{Introduction}

The most synthesised inhibitors used to secure metals against corrosion are generally a source of pollution hazards. The attempts to highlight environmentally friendly processes are reoriented to the use of natural products which are known as their environmental and acceptable ecological properties. Also, naturally occurring antioxidants are cheap and readily available and renewable sources of materials. Recently, many works show that they can be used as corrosion inhibitors; we cite natural honey [1], henna [2], occimum bascilicum [3], ginger [4], extracts of fruits [5], thym [6], jojoba oil [7], rosemary

\footnotetext{
* Corresponding author. E-mail address: hammoutib@yahoo.fr
} 
oil [8, 9], eugenol [10]. Also, an extracted of an antibiotic and pyrrolidine alkaloids: bgugaine is shown to be an efficient corrosion inhibitor of iron corrosion in $1 \mathrm{M} \mathrm{HCl}[11,12]$.

In this optic, the encouraging results obtained by artemisia oil on the corrosion of steel in $\mathrm{HCl}$ [13] and $\mathrm{H}_{3} \mathrm{PO}_{4}$ [14] have incited us to test its extracts on steel corrosion in $\mathrm{H}_{2} \mathrm{SO}_{4}$. The literature shows that it received considerable attention as a promising and potent antimalarial drug for its stage specificity, its rather low toxicity. Literature shows that davanone (Fig .1) is the major constituent of artemesia herba alba in Morocco [15, 16]. Camphene, cineol-1,8, chrysanthenone, $\alpha$ and $\beta$-thujone and camphor are also detected. Recently, davanone has also the higher percentage $(51.2 \%)$ in artemisia of Spanish origin [17] and Montenegro [18].

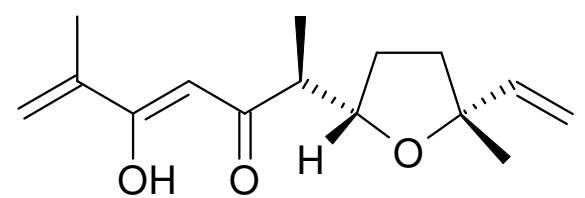

Figure 1. Molecular structural of davanone $(249 \mathrm{~g} / \mathrm{mol})$.

The objective of the present paper is to study by gravimetric and polarisation methods the effect of extract of the natural artemisia on the corrosion of steel in $0.5 \mathrm{M} \mathrm{H}_{2} \mathrm{SO}_{4}$ solution. The effect of temperature between 298 and $353 \mathrm{~K}$ leads to the activation and adsorption of thermodynamic parameters.

\section{Experimental details}

Prior to all measurements, the steel samples $(0.09 \% \mathrm{P} ; 0.38 \% \mathrm{Si} ; 0.01 \% \mathrm{Al}$; $0.05 \% \mathrm{Mn} ; 0.21 \% \mathrm{C} ; 0.05 \% \mathrm{~S}$ and the remainder iron) are polished with different emery paper up to 1000 grade, washed thoroughly with bidistilled water, degreased and dried with acetone.

The aggressive solution $\left(0.5 \mathrm{M} \mathrm{H}_{2} \mathrm{SO}_{4}\right)$ is prepared by dilution of Analytical Grade $98 \% \mathrm{H}_{2} \mathrm{SO}_{4}$ with bidistilled water. $10 \mathrm{~g}$ of dried and powdered leaves of artemisia abyssinica are refluxed with 1 litre of $0.5 \mathrm{M} \mathrm{H}_{2} \mathrm{SO}_{4}$ at $373 \mathrm{~K}$ for $5 \mathrm{~h}$. The extract was filtered from this stock solution from which solutions at different concentrations of the natural inhibitor are prepared.

Gravimetric measurements are carried out in double walled glass cell equipped with a thermostatic cooling condenser. One specimen is immersed in $100 \mathrm{~cm}^{3}$ of acid solution. The steel specimens used have a rectangular form $(2 \mathrm{~cm} \times 2 \mathrm{~cm} \times$ $0.05 \mathrm{~cm})$.

Electrochemical measurements are carried out in a conventional three-electrode electrolysis cylindrical pyrex glass cell. The temperature is controlled at $298 \pm$ $0.5 \mathrm{~K}$. The working electrode (WE) in the form of disc is cut from steel, has a geometric area of $1 \mathrm{~cm}^{2}$ and is embedded in polytetrafluoroethylene (PTFE). A saturated calomel electrode (SCE) and a platinum electrode are used as reference and auxiliary electrodes, respectively. Running on an IBM compatible personal computer, the 352 Soft Corr $^{\mathrm{TM}}$ III software communicates with EG\&G 
Instruments potentiostat-galvanostat model 263 at a scan rate of $20 \mathrm{mV} / \mathrm{min}$. Before recording the polarisation curves, the steel electrode is polarized at -800 $\mathrm{mV}$ vs. SCE for $10 \mathrm{~min}$. Polarisation curves are then recorded from $-800 \mathrm{mV}$ to anodic potentials. Values of linear polarisation resistance $\left(R_{p}\right)$ are directly given by 352 Soft Corr ${ }^{\mathrm{TM}}$ III software obtained from the current potential plots. The test solution is de-aerated by pure nitrogen. Gas pebbling is maintained through the experiments.

Gravimetric and polarisation results obtained are deduced from the mean value of triplicate measurements.

\section{Results and discussion}

Weight loss measurements

The corrosion rate in $0.5 \mathrm{M} \mathrm{H}_{2} \mathrm{SO}_{4}\left(\mathrm{~W}_{\text {corr }}^{\mathrm{o}}\right)$ and at various concentrations of natural tested plant $\left(\mathrm{W}_{\text {corr }}\right)$ is determined after $6 \mathrm{~h}$ immersion. Values of corrosion rate and inhibition efficiencies are given in Table 1 . The inhibition efficiency $\mathrm{E}_{\mathrm{w}}$, is determined by the relation:

$$
E_{w} \%=100 \times\left(1-\frac{W_{\text {Corr }}}{W_{\text {Corr }}^{\circ}}\right)
$$

where $\mathrm{W}_{\text {corr }}$ and $\mathrm{W}_{\text {corr }}^{\circ}$ are the corrosion rates of steel in the presence and absence of artemisia, respectively.

Table 1. Gravimetric results of steel in acid with and without artemisia at various contents $(\mathrm{t}=6 \mathrm{~h})$.

\begin{tabular}{|c|c|c|}
\hline Concentration $(\mathrm{g} / \mathrm{L})$ & $\mathrm{W}_{\text {corr }}\left(\mathrm{mg} / \mathrm{cm}^{2} \cdot \mathrm{h}\right)$ & $\mathrm{E}_{\mathrm{W}} \%$ \\
\hline Blank & 1.608 & - \\
\hline $10^{-3}$ & 1.254 & 22 \\
\hline $10^{-2}$ & 0.691 & 57 \\
\hline $10^{-1}$ & 0.418 & 74 \\
\hline 1 & 0.209 & 87 \\
\hline 10 & 0.081 & 95 \\
\hline
\end{tabular}

The addition of artemisia reduces the corrosion rate in $\mathrm{H}_{2} \mathrm{SO}_{4}$ solution. The inhibitory effect increases with the increase of artemisia concentration. E\% reaches a maximum of $95 \%$ at $10 \mathrm{~g} / \mathrm{L}$ for artemisia. This result shows that artemisia extract is a good inhibitor of steel corrosion in $0.5 \mathrm{M} \mathrm{H}_{2} \mathrm{SO}_{4}$ solution.

\section{Polarisation measurements}

Polarisation behaviour of steel in $0.5 \mathrm{M} \mathrm{H}_{2} \mathrm{SO}_{4}$ in the presence and absence of artemisia is shown in Fig. 2. Table 2 gives values of corrosion current density $\left(\mathrm{I}_{\text {corr }}\right)$, corrosion potential $\left(\mathrm{E}_{\text {corr }}\right)$, cathodic Tafel slope $\left(\mathrm{b}_{\mathrm{c}}\right)$, anodic Tafel slope $\left(b_{a}\right)$, and polarisation resistance $\left(R_{P}\right)$. The inhibition efficiency $\left(E_{I} \%\right)$ is calculated by the relation: 


$$
E_{I}(\%)=\left(1-\frac{I_{\text {corr }}}{I_{\text {corr }}^{0}}\right) \cdot 100
$$

where $\mathrm{I}_{\text {corr }}^{0}$ and $\mathrm{I}_{\text {corr }}$ are the uninhibited and inhibited corrosion current densities, respectively, determined by extrapolation of cathodic Tafel lines to corrosion potential.

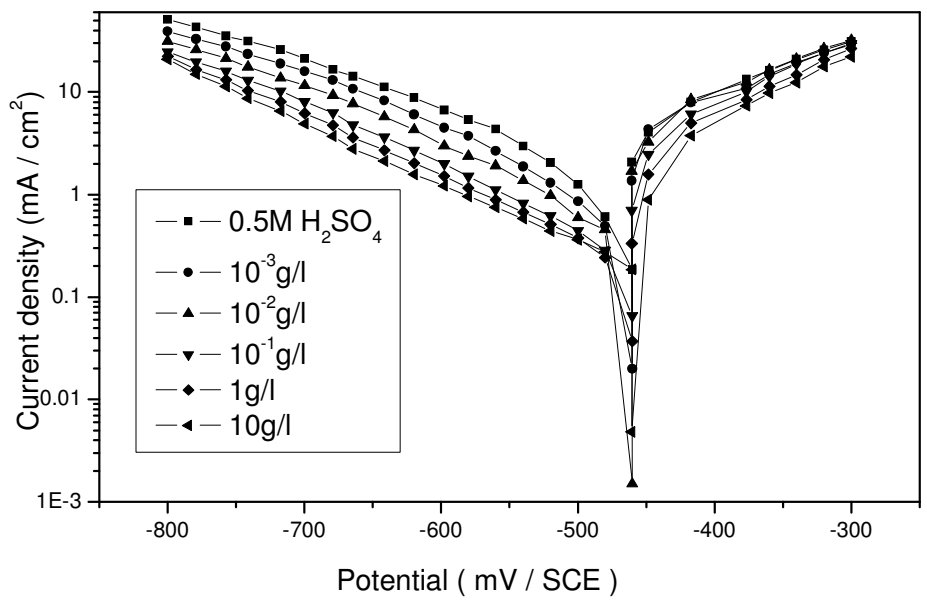

Figure 2. Polarisation curves of steel in $\mathrm{H}_{2} \mathrm{SO}_{4}$ at various concentrations of artemisia at $298 \mathrm{~K}$.

Table 2. Electrochemical parameters of steel in $0.5 \mathrm{M} \mathrm{H}_{2} \mathrm{SO}_{4}+$ artemisia at various concentrations.

\begin{tabular}{|c|c|c|c|c|c|c|c|}
\hline $\begin{array}{c}\text { Concentration } \\
(\mathrm{g} / \mathrm{L})\end{array}$ & $\begin{array}{c}\mathrm{E}_{\text {corr }} \\
(\mathrm{mV} / \mathrm{SCE})\end{array}$ & $\begin{array}{c}\beta_{\mathrm{c}} \\
(\mathrm{mV} / \mathrm{dec})\end{array}$ & $\begin{array}{c}\beta_{\mathrm{a}} \\
(\mathrm{mV} / \mathrm{dec})\end{array}$ & $\begin{array}{c}\mathrm{I}_{\text {corr }} \\
\left(\mu \mathrm{A} / \mathrm{cm}^{2}\right)\end{array}$ & $\begin{array}{c}\mathrm{E}_{\mathrm{I}} \\
\%\end{array}$ & $\begin{array}{c}\mathrm{R}_{\mathrm{P}} \\
(\Omega / \mathrm{cm})\end{array}$ & $\begin{array}{c}\mathrm{E}_{\mathrm{R}} \\
\%\end{array}$ \\
\hline Blank & -474 & 166 & 52 & 552 & - & 31 & - \\
\hline $10^{-3}$ & -463 & 143 & 61 & 440 & 20 & 42 & 25 \\
\hline $10^{-2}$ & -472 & 127 & 61 & 285 & 48 & 63 & 51 \\
\hline $10^{-1}$ & -471 & 151 & 57 & 169 & 69 & 106 & 71 \\
\hline 1 & -474 & 150 & 47 & 66 & 88 & 206 & 85 \\
\hline 10 & -473 & 171 & 68 & 50 & 91 & 517 & 94 \\
\hline
\end{tabular}

As it is shown in Fig. 1 and Table 2, cathodic polarisation curves rise to parallel Tafel lines indicating that the hydrogen evolution reaction is control activation. Thus the presence of natural artemisia does not affect the mechanism of this process. The addition of natural substance causes a decrease of the current density. Values of $E_{\text {corr }}$ and cathodic Tafel slope $\left(b_{c}\right)$ do not change when the concentration increases. The results demonstrate that the hydrogen reduction is inhibited and that the inhibition efficiency increases with inhibitor concentration to reach a maximum value of $91 \%$ at $10 \mathrm{~g} / \mathrm{L}$ of artemisia. 
In the anodic range, the polarisation curves of steel in $0.5 \mathrm{M} \mathrm{H}_{2} \mathrm{SO}_{4}$ with and without artemisia show that the presence of inhibitor decreases the current density. This fact means that artemisia inhibits anodic reaction and acts as a mixed type inhibitor.

The corresponding polarisation resistance $\left(\mathrm{R}_{\mathrm{P}}\right)$ values of steel in $0.5 \mathrm{M} \mathrm{H}_{2} \mathrm{SO}_{4}$ in the presence and absence of different concentrations of the inhibitor are also given in Table 2 . The inhibition efficiency $\mathrm{E}_{\mathrm{R}} \%$ is calculated as follows:

$$
E_{R} \%=100 .\left(1-\frac{R_{P}}{R_{P}^{\prime}}\right)
$$

where $R_{P}$ and $R_{P}^{\prime}$ are the polarisation resistance with and without the inhibitor, respectively.

We remark that $R_{P}$ increases with increasing the inhibitor concentration. This in turn leads to a decrease in $\mathrm{I}_{\text {corr }}$ values. The efficiency increases with the product content and attains 94\%.

\section{Effect of temperature}

The influence of temperature on the corrosion behaviour of steel/acid added of artemisia at various concentrations is investigated by weight-loss trends in the temperature range 298-353 $\mathrm{K}$ during $1 \mathrm{~h}$ of immersion. The variation of the inhibition efficiency of artemisia with temperature is shown in Fig. 3. E\% increases with temperature to attain $99 \%$ at $353 \mathrm{~K}$.

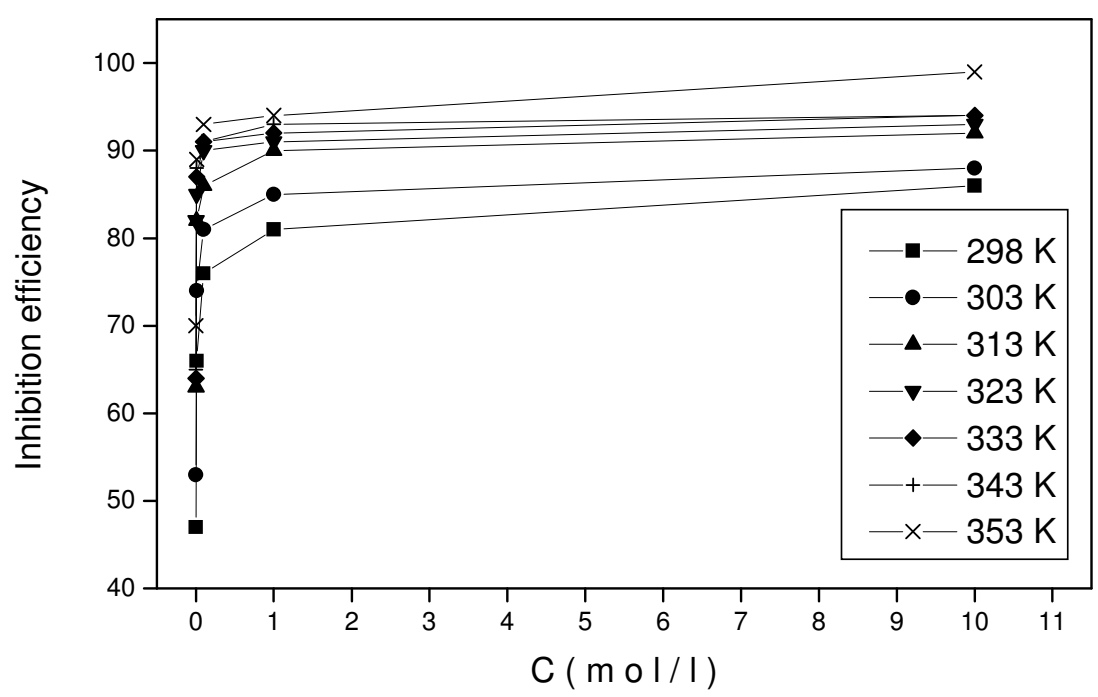

Figure 3. Evolution of efficiency at various concentrations of artemisia at different temperatures.

The activation energy can be determined from Arrhenius plots for steel corrosion rate presented in Fig. 4 by the following relation: 


$$
\mathrm{W}=\mathrm{K} \cdot \exp \left(-\mathrm{E}_{\mathrm{a}} / \mathrm{RT}\right) \text { and } \mathrm{W}^{\prime}=\mathrm{K} \cdot \exp \left(-\mathrm{E}_{\mathrm{a}}{ }^{\prime} / \mathrm{RT}\right)
$$

where $E_{a}$ and $E_{a}^{\prime}$ are the apparent activation energies for the corrosion in the absence and presence of the inhibitor at different concentrations, respectively.

It is obvious that the activation energy of the inhibited solution in this study decreases by increasing the concentration of artemisia. The increase of $\mathrm{E} \%$ and decrease of $E_{a}$ are generally regarded as chemisorption [19, 20].

For calculating the entropy $\Delta \mathrm{S}^{*}$ and enthalpy $\Delta \mathrm{H}^{*}$ of activation, the alternative formulation of the Arrhenius equation is the transition state equation [21-23]:

$$
W=\frac{R T}{N h} \exp \left(\frac{\Delta S^{*}}{R}\right) \exp \left(-\frac{\Delta H^{*}}{R T}\right)
$$

being h the Plank's constant, and N Avogadro's number.

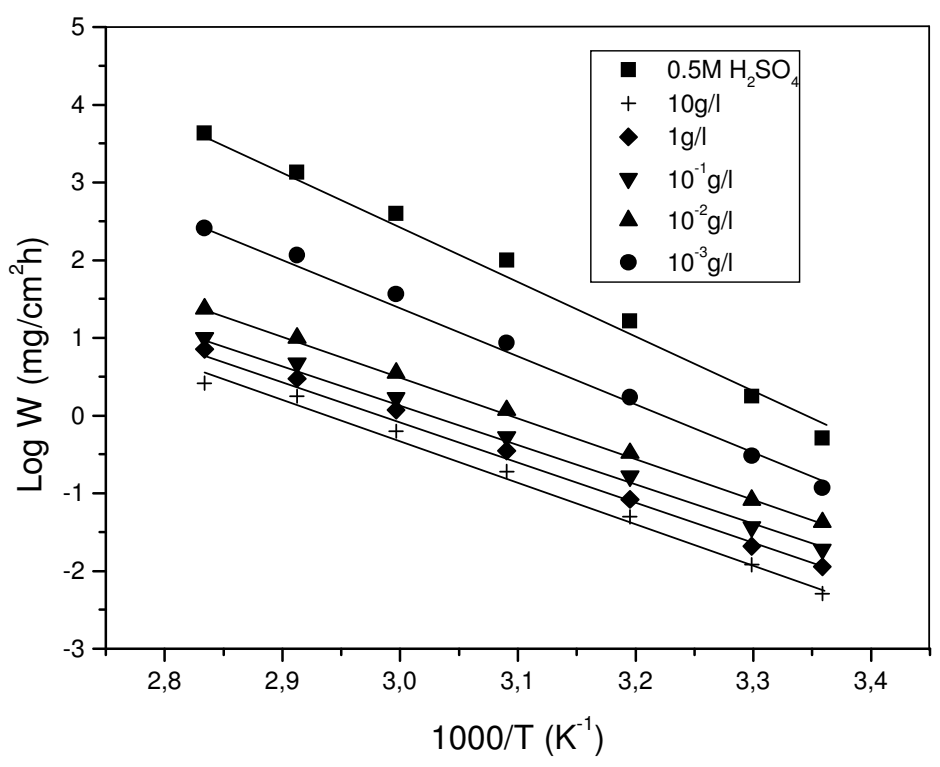

Figure 4. Arrhenius plots for the dissolution of steel in $0.5 \mathrm{M} \mathrm{H}_{2} \mathrm{SO}_{4}$ in the absence and presence of artemisia.

Fig. 5 shows straight lines of plots of $\log \left(\mathrm{W}_{\text {corr }} / \mathrm{T}\right)$ vs. $1 / \mathrm{T}$ with a slope of $\Delta \mathrm{H}^{*} / \mathrm{R}$ and an intercept of $\left(\log (\mathrm{R} / \mathrm{Nh})+\Delta \mathrm{S}^{*} / \mathrm{R}\right)$. Values of $\mathrm{E}_{\mathrm{a}}, \Delta \mathrm{H}^{*}$ and $\Delta \mathrm{S}^{*}$ are collected in Table 3 . The data show that the thermodynamic parameters $\left(\Delta H^{*}\right.$ and $\Delta \mathrm{S}^{*}$ ) of the dissolution reaction of steel in $0.5 \mathrm{M} \mathrm{H}_{2} \mathrm{SO}_{4}$ in the presence of artemisia are lower than those of the non-inhibited solution. The positive values of $\Delta \mathrm{H}^{*}$ suggest that the dissolution process is an exothermic phenomenon and that the dissolution of steel is difficult. Also, the entropy $\Delta \mathrm{S}^{*}$ widely decreases with the content of the inhibitor. This means the formation of an ordered stable layer of inhibitor on the steel surface [24]. 


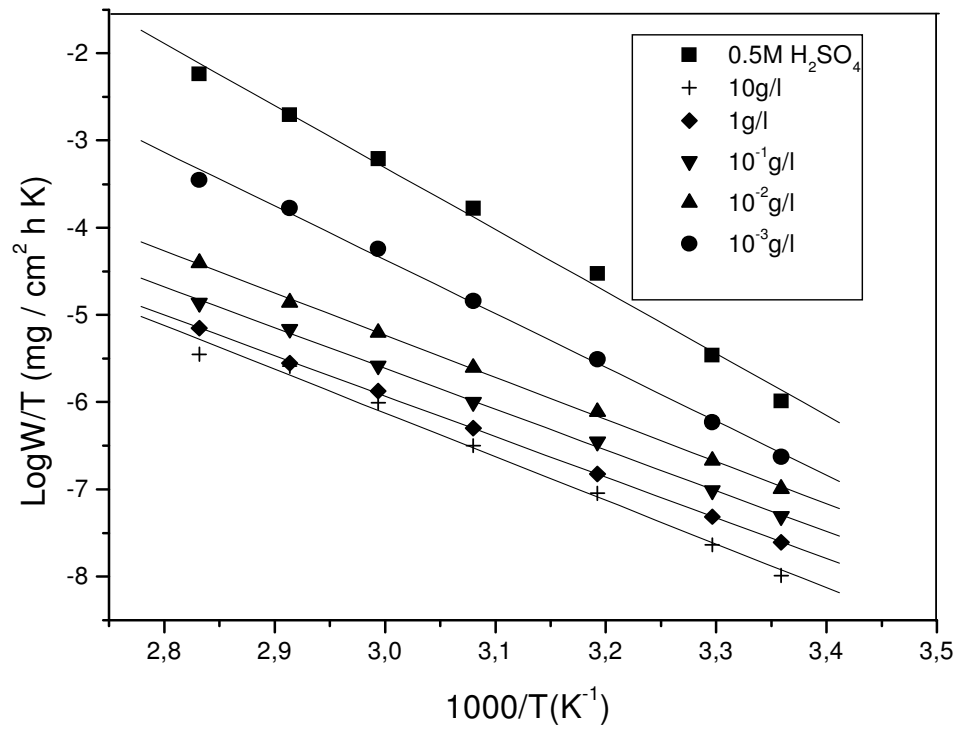

Figure 5. Plots of $\log (\mathrm{W} / \mathrm{T})$ vs. 1/T for steel in different additives of artemisia.

Table 3. Activation parameters of steel in $0.5 \mathrm{M} \mathrm{H}_{2} \mathrm{SO}_{4}$ with and without artemisia.

\begin{tabular}{|c|c|c|c|}
\hline Concentration $(\mathrm{g} / \mathrm{L})$ & $\mathrm{E}_{\mathrm{a}}\left(\mathrm{kJ} \cdot \mathrm{mol}^{-1}\right)$ & $\Delta \mathrm{H}^{*}\left(\mathrm{~kJ} \cdot \mathrm{mol}^{-1}\right)$ & $\Delta \mathrm{S}^{*}\left(\mathrm{~J}^{-1} \mathrm{~mol}^{-1} \mathrm{~K}^{-1}\right)$ \\
\hline Blank & 61.83 & 59.15 & -47.75 \\
\hline $10^{-3}$ & 54.08 & 51.37 & -79.88 \\
\hline $10^{-2}$ & 43.98 & 40.21 & -12055 \\
\hline $10^{-1}$ & 43.81 & 38.93 & -127.56 \\
\hline 1 & 45.40 & 38.71 & -130.87 \\
\hline 10 & 44.42 & 37.42 & -137.87 \\
\hline
\end{tabular}

\section{Adsorption isotherm}

Fig. 6 shows the linear dependence of $\mathrm{C} / \theta$ as a function of $\mathrm{C}$, where $\theta$ is the surface coverage determined by the ratio $\mathrm{E} \% / 100$. The inhibitor adsorbs on the steel surface according to the Langmuir kind isotherm model by the relation [25]:

$$
\frac{C}{\theta}=\frac{1}{K}+C \quad \text { with } \quad K=A \exp \left(\frac{-\Delta G_{a d s}}{R T}\right)
$$

where $\mathrm{K}$ is the equilibrium constant of the adsorption process. 


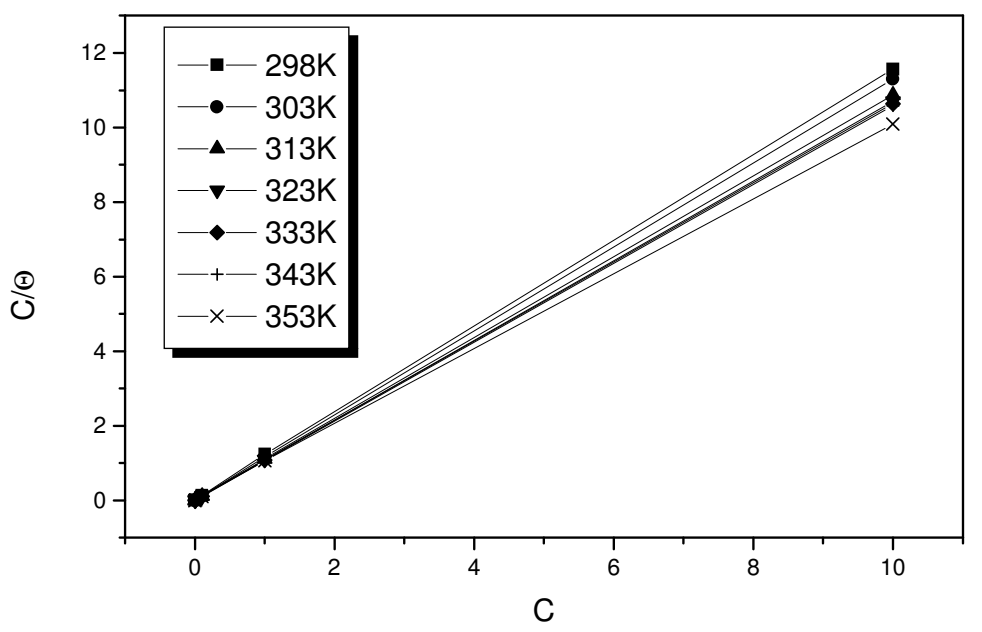

Figure 6. Langmuir's adsorption isotherm model for artemisia in $0.5 \mathrm{M} \mathrm{H}_{2} \mathrm{SO}_{4}$ at different temperatures.

Thermodynamic model is a good tool to explain the adsorption phenomenon of the inhibitor molecule. $\Delta \mathrm{H}_{\mathrm{ads}}$ may be determined from the Van't Hoff equation [26-27]:

$$
\ln \mathrm{K}=-\frac{\Delta H_{a d s}}{\mathrm{RT}}+\text { Constant }
$$

where $\Delta \mathrm{H}_{\mathrm{ads}}$ and $K$ are the adsorption heat and adsorptive equilibrium constant, respectively.

Fig. 7 is the straight line $\ln \mathrm{K} \sim 1 / \mathrm{T}$. The adsorption heat $\left(\Delta \mathrm{H}_{\mathrm{ads}}\right)$ can be approximately regarded as the standard adsorption heat $\left(\Delta \mathrm{H}_{\mathrm{ads}}\right)$ under the experimental conditions [27-28].

Then the standard adsorption entropy $\Delta \mathrm{S}_{\mathrm{ads}}$ can be obtained by the thermodynamic basic equation $\Delta \mathrm{G}_{\mathrm{ads}}=\Delta \mathrm{H}_{\mathrm{ads}}-\mathrm{T} \Delta \mathrm{S}_{\mathrm{ads}}$ (Fig. 8). Data obtained from this figure are $\Delta \mathrm{H}_{\mathrm{ads}}=24.14 \mathrm{~kJ} / \mathrm{mol}$ and $\Delta \mathrm{S}_{\mathrm{ads}}=-194.3 \mathrm{~J} / \mathrm{mol} . \mathrm{K}$. Adsorption equilibrium constants $\mathrm{K}$ and other thermodynamic parameters for the adsorption process are listed in Table 4.

The negative value of $\Delta \mathrm{G}_{\mathrm{ads}}$ means that the adsorption of artemisia extract on steel surface is a spontaneous process, and furthermore the negative values of $\Delta \mathrm{G}_{\mathrm{ads}}$ also show the strong interaction of the inhibitor molecule onto the steel surface [29, 30].

It was found that $\Delta \mathrm{G}_{\mathrm{ads}}$ increases negatively with increasing the temperature; this phenomenon once again indicates that the adsorption is favourable with increasing experimental temperature and dominates on the desorption of the inhibitor from the steel surface. 


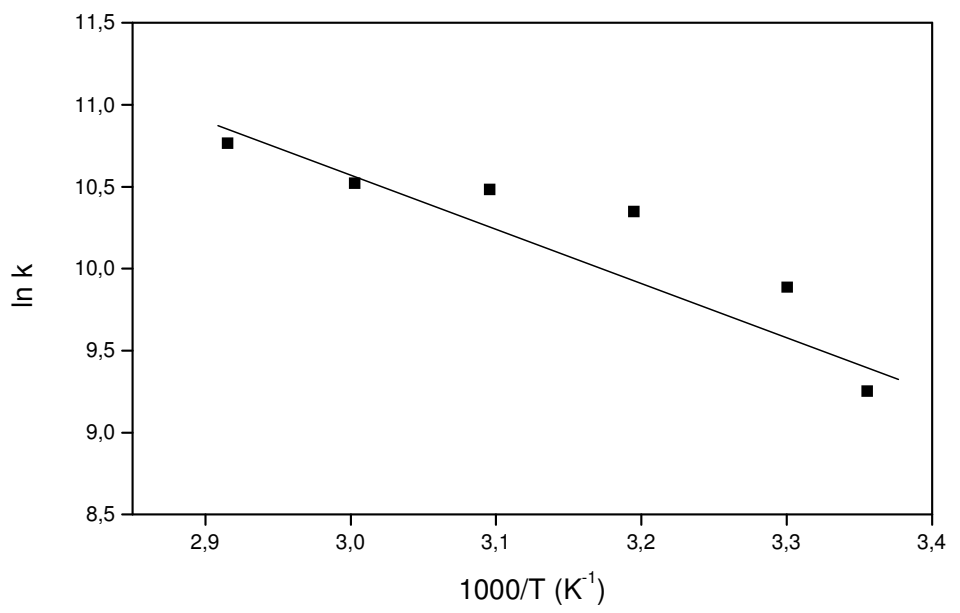

Figure 7. Relationship between $\ln \mathrm{K}$ and $1 / \mathrm{T}$.

The values of thermodynamic parameters for the adsorption of inhibitors can provide valuable information about the mechanism of corrosion inhibition. The endothermic adsorption process $\left(\Delta \mathrm{H}_{\mathrm{ads}}>0\right)$ is attributed unequivocally to chemisorption [31], while generally, an exothermic adsorption process $\left(\Delta \mathrm{H}_{\mathrm{ads}}<\right.$ 0 ) may involve either physisorption or chemisorption or a mixture of both the processes. In the present case, the positive sign of $\Delta \mathrm{H}_{\text {ads }}^{\circ}(24.44 \mathrm{~kJ} / \mathrm{mol})$ indicates that the adsorption of inhibitor molecules is an endothermic process [32]. The positive values of $\Delta \mathrm{S}_{\mathrm{ads}}$ indicate that the adsorption is a process accompanied by an increase in entropy. Therefore, the values of $\Delta \mathrm{H}_{\mathrm{ads}}$ and $\Delta \mathrm{S}_{\mathrm{ads}}$ obtained by both methods are in good agreement.

Table 4. Thermodynamic data for studied artemisia from experimental adsorption isotherm.

\begin{tabular}{|c|c|l|c|c|c|}
\hline $\mathrm{T}(\mathrm{K})$ & Slope & $\mathrm{k}$ & $\Delta \mathrm{G}_{\mathrm{ads}}(\mathrm{kJ} / \mathrm{mol})$ & $\Delta \mathrm{H}_{\mathrm{ads}}(\mathrm{kJ} / \mathrm{mol})$ & $\Delta \mathrm{S}_{\mathrm{ads}}\left(\mathrm{J} \mathrm{mol}^{-1} \mathrm{k}^{-1}\right)$ \\
\hline 298 & 1.15 & 10438,08 & -32.9 & 24.44 & 192.42 \\
\hline 303 & 1.12 & 19646,1 & -35.0 & 24.44 & 196.17 \\
\hline 313 & 1.08 & 31199,7 & -37.4 & 24.44 & 197.57 \\
\hline 323 & 1.06 & 35656,8 & -39.0 & 24.44 & 196.40 \\
\hline 333 & 1.06 & 37051,2 & -40.3 & 24.44 & 194.41 \\
\hline 343 & 1.05 & 47310 & -42.2 & 24.44 & 194.86 \\
\hline
\end{tabular}


The values of $\Delta \mathrm{G}_{\mathrm{ads}}$ are negative indicating that natural substance is strongly adsorbed on the metal surface [33]. Furthermore $\Delta \mathrm{G}_{\mathrm{ads}}$ becomes more negative with the rise of temperature showing the high protection of natural plant at $353 \mathrm{~K}$ $(99 \%)$.

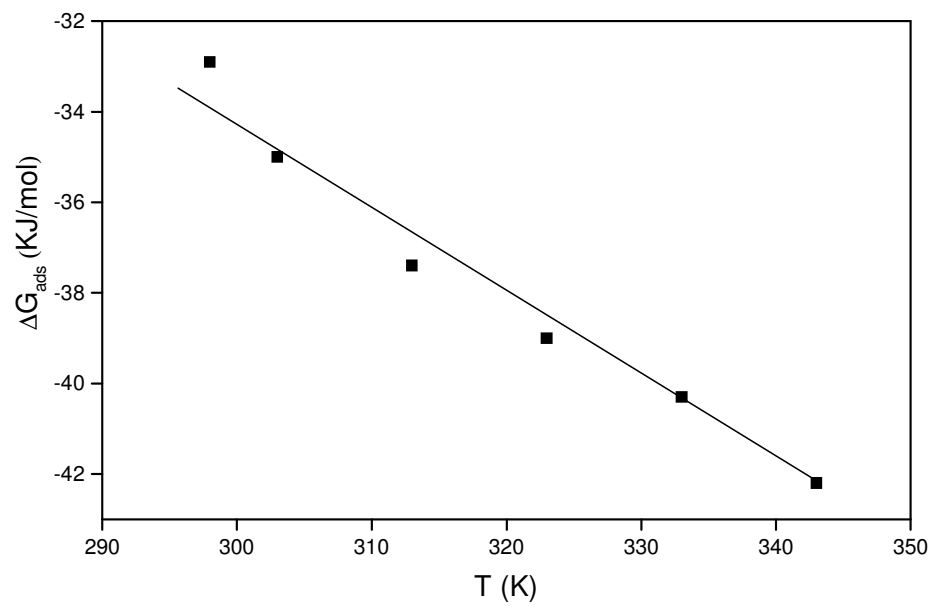

Figure 8. Variation of $\Delta \mathrm{G}_{\mathrm{ads}}$ with temperature.

The adsorption phenomenon of davanone of oil may be explained by tautomeric equilibrium:<smiles>C=C[C@]1(C)CC[C@@H]([C@@H](C)C(=O)CC(=O)C(C)=C=C=C=C=C[C@]2(C)CC[C@@H]([C@@H](C)C(=O)/C=C(\O)C(=C)C)O2)O1</smiles>

And also the davanone molecular may be stabilized by intramolecular hydrogen bond which enhances efficiency. Such results were obtained by other works [33].<smiles></smiles>

Since davanone is a diketone compound, the inhibitory action may be also interpreted by the formations of $\mathrm{Fe}(\mathrm{II})$-davanone complex as recently shown in the literature [34]. 


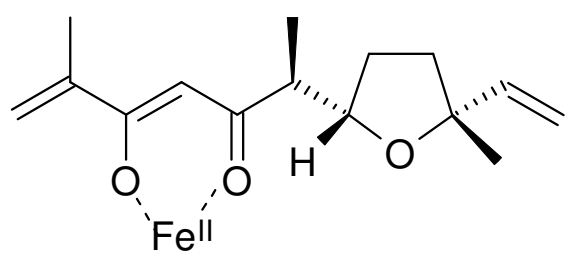

\section{Conclusion}

- Artemisia extract acts as a mixed type inhibitor for the corrosion of steel in 0.5 $\mathrm{M} \mathrm{H}_{2} \mathrm{SO}_{4}$ without modifying the mechanism of hydrogen evolution reaction.

- The polarisation resistance increases with the content of the inhibitor.

- The adsorption of artemisia on the steel surface in sulphuric acid obeys to the Langmuir adsorption isotherm model.

- The inhibition efficiency of artemisia increases with the temperature and the activation corrosion energy decreases in presence of the inhibitor.

- Gravimetric, electrochemical and polarisation resistance measurements are in good agreement.

\section{References}

1. A.Y. El-Etre, M. Abdallah, Corros. Sci. 42 (2000) 731.

2. A. Chetouani, B. Hammouti, Bull. Electrochem. 18 (2002) 131.

3. E.E. Oguzie, A.I. Onuchukwu, P.C. Okafor, E.E. Ebenzo, Pigm. Resin Technol. 35 (2006) 30 .

4. A. Bouyanzer, B. Hammouti, Bull. Electrochem. 20 (2004) 131.

5. A.A. El Hosary, M.M. Gawish, R.M. Saleh, Proc. $2^{\text {nd }}$ Int. Sym. Ind. Oriented Basic Electrochem. Madras, India (1980).

6. A. Chetouani, B. Hammouti, Bull. Electrochem. 20 (2004).

7. A. Chetouani, B. Hammouti, M. Benkaddour, Pigm. Resin Technol. 33 (2004) 26.

8. E.L. Chaieb, A. Bouyanzer, B. Hammouti, M. Benkaddour, M. Berrabah, Trans. SAEST 39 (2004) 58.

9. M. Bendahou, M. Benabdellah, B. Hammouti, Pigm. Resin Technol. 35 (2006) 95.

10. E.L. Chaieb, A. Bouyanzer, B. Hammouti, M. Benkaddour, Appl. Surf. Sci. 249 (2005) 183.

11. B. Hammouti, S. Kertit, M. Melhaoui, Bull. Electrochem. 11 (1995) 553.

12. B. Hammouti, S. Kertit, M. Melhaoui, Bull. Electrochem. 13 (1997) 97.

13. M. Benabdellah, M. Bendahou, B. Hammouti, M. Benkaddour, Appl. Surf. Sci.

(Corrected Proof) (2006).

14. A.Bouyanzer, B. Hammouti, Pigm. Resin Technol. 31 (2004) 287.

15. B. Benjilali, J. Sarris, H. Richard, Sci. Aliment. 2 (1982) 515. 
16. B.M. Lawrence, Armoise oil. Natural Flavor and Fragrance Materials. In: Perfumer and Flavorist (Ed.), Essential Oils 1988-1991. Allured Publishing Corporation, Carol Stream, IL, (1993) p. 52.

17. S. Salido, L.R. Valenzuela, J. Altajeros, M. Nogueras, A. Sanchez, E. Cano, Biochem. Syst. Ecol. 32 (2004) 265.

18. V. Tesevic, S. Milosavljevic, V. Vajs, P. Janackovic, D.L. Jovic, L. Vujisic, Biochem. System. Ecol. 32 (2004) 525.

19. T. Szauer, A. Brandt, Electrochim. Acta 26 (1981) 1209.

20. A. Popova, E. Sokolova, S. Raicheva, M. Chritov, Corros. Sci. 45 (2003) 33.

21. A.J. Bard, L.R. Faulkner, Electrochemical Methods, Wiley \& Sons, 1997.

22. P.W. Atkins, Eléments de Chimie Physique, Ed. De Boeck Université, (1998), p. 258.

23. I.N. Levine, Physical Chemistry, Ed. McGraw-Hill Kogakusha, Ltd, ISBN 0-07-037418-X, (1978), p. 768.

24. M.M. Osman, Anti-Corros. Meth. Mater. 45 (1998) 176.

25. I. Langmuir, J. Amer. Chem. Soc. 39 (1947) 1848.

26. L.B. Tang, G.N. Mu, G.H. Liu, Corros. Sci. 45 (2003) 2251.

27. T.P. Zhao, G.N. Mu, Corros. Sci. 41 (1999) 1937.

28. G.N. Mu, X.M. Li, F. Li, Mater. Chem. Phys. 86 (2004) 59.

29. M. Elachouri, M.S. Hajji, M. Salem, S. Kertit, J. Aride, R. Coudert, E. Essassi, Corrosion 52 (1996) 103.

30. B.V. Savitri, S. Mayanna, Ind. J. Chem. Technol. 3 (1996) 256.

31. W. Durnie, R.D. Marco, A. Jefferson, B. Kinsella, J. Electrochem. Soc. 146 (1999) 1751.

32. M.K. Gomma, M.H. Wahdan, Mater. Chem. Phys. 39 (1995) 209.

33. F. Bentiss, M. Traisnel, M. Lagrenée, Corros. Sci. 42 (2000) 127.

34. T.K. Paine, H. Zheng, L. Que, J. Inorg. Chem. 44 (2005) 475. 